\title{
人検出の精度向上とそのデータ活用 Human detection and mapping application
}

\author{
○学 松倉 広宜（新潟大院） 正 大矢 誠（新潟大） \\ Yutaka ABE, Niigata Graduate School, Ikarasininotyou8050, Niigata-city, Niigata \\ Makoto OYA, Niigata University, Ikarasininotyou8050, Niigata-city, Niigata
}

Key Words: Image Processing , Human detection

\section{1. 緒言}

人検出処理とは、ビデオカメラ等で撮影された映像の中 から画像処理技術を利用して人領域のみを検出するもので ある。その手法としては、映像データに対して閾值処理を 行い、形状特徵によって求める領域を特定するのが一般的 である。これについては、近年では映像記憶ハードが著し く進歩した結果、様々な分野での応用が期待されている。 例えば、サッカー選手 22 人の走行距離やダッシュの回数の 計測あるいは、スーパーなどで消費者がどのような行動を 取るかといったデータを集めてマーケティングに反映させ る、というような用いられ方もされている。

しかし、これらのハードの進化に対して、ソフト面での 進歩が遅れを取っているのが現状である。さらに既存の人 検出処理では、混雑レベルが非常に高くなった場合や、高 速で人が動く場合、また背景が暗い場合などでは精度が著 しく落ちる傾向があり、検出の正しさが求められるなど、 様々な問題にも対処する必要がある。これらの問題を踏ま え本研究では、人検出処理の精度向上と応用分野の開発を 目的として研究を行った。

\section{2. 撮影条件}

本研究で使用する映像データは、新潟大学工学部学生玄 関 2 階のデッキから見た入口付近の映像である。撮影条件 は午前 10 時から 5 分間行い、照明は点いておらず天気は晴 れである。撮影した映像データを 1 秒当たり 30 コマの静止 画像に等間隔に切り取り処理を行った。画像の解像度は、 640×368 ピクセルである。画像の一例を図 1 に示す。
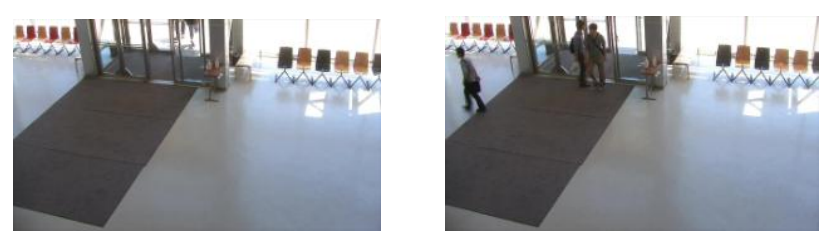

Fig.1 Image

\section{3. 移動体領域の抽出}

撮影した画像をコンピューターに取り込みながら、人検 出の前段階として必要となる移動体領域の抽出を行う。

処理の流れを図 2 に示寸。本研究では、移動体の検出方 法としてオプティカルフローを用いた。オプティカルフロ 一とは、2 枚の連続する画像間の動きに関する情報を輝度 值に置き換える処理である。その後、オプティカルフロー で得られた画像に閾值処理を行い、移動体である可能性が 高い領域のみを残す。さらに、穴埋め処理による補正、領 域ラベリングを行い、不要な微小領域をノイズ除去処理で 除くことで、人と思われる移動体領域のみを抽出すること ができる。

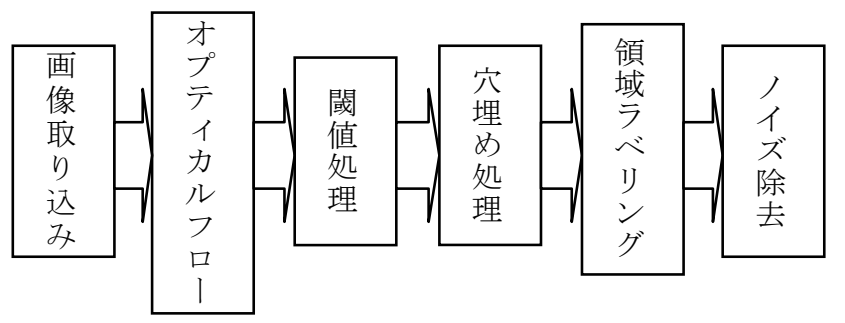

Fig.2 Flow of moving area abstraction

\section{4. 人領域の特定}

移動体領域から人領域を特定する際に、複数の領域が結 合している場合があるので、最初にこれを分割する処理を 行っておく。その後、移動体領域の中から人間の形状特徵 の中でも有効性の高いと思われるものを用いて人領域のみ を特定した。人領域の特定処理の流れを図 3 に示す。次節 以降に各処理について述べる。

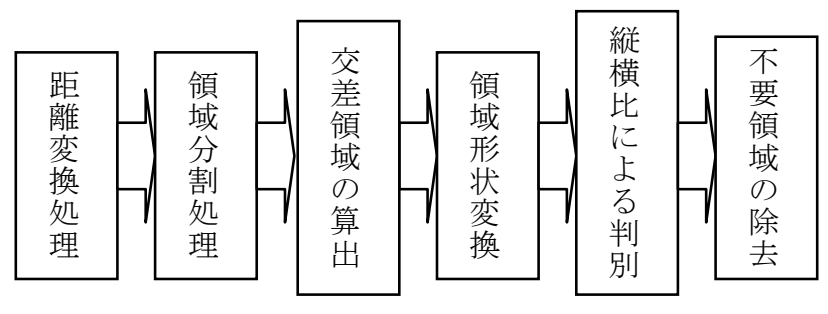

Fig.3 Flow of specifying human area

\section{4-1 距離変換処理}

次節の分割処理を行うために必要となる距離変換処理に ついて述べる。2 值画像は、領域の存在を「1」と「0」の 2 つの值で区別する 2 次元配列と考えられる。そして、ある 形状を「1」の集合によって表現するものである。このとき、 領域境界から領域内のある画素までの距離を求め、その值 をその画素の值に置き換える処理が距離変換処理であり、 領域の中心部に近いほど大きな值を取る。これによって、 領域の形状の骨格の様子を知ることができる。

なお、距離值は縦横に走査して求めた最短值であり、斜 めの距離は求めていない。

\section{4-2 領域分割処理}

複数の移動体領域が結合した領域を分割し、個々の移動 体領域として認識する処理について説明する。本研究では、 領域分割を行うために用いた分水嶺アルゴリズムは、画像 の輝度勾配を山の領として、山の高い(=輝度值の高い)位置 から水の流れ込む区域をひとつの領域として分割するアル ゴリズムである。このアルゴリズムを距離変換処理によっ て得られた画像に対して用いることで、結合した領域の境 
界線が判明する。この境界線の画像と、閾值処理で得られ た画像で交差領域の算出処理をすることで、個々の移動体 に分割された画像が得られる。サンプル画像に領域分割を 行った結果を図 4 に示す。オプティカルフローは処理から 得られた左側の画像では、赤で示された領域は 2 人が結合 した状態であるが、領域分割によって各々の人物に分離さ れたことが分かる。
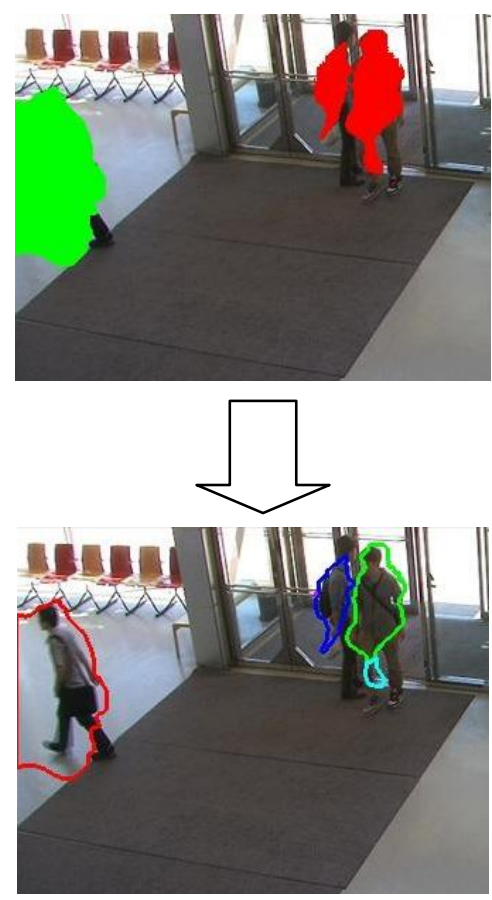

Fig.4 Region division image

\section{4-3 縦横比による判別}

前節までの処理で得られた移動体の画像から、人領域だ けを抽出していく。そのために、人の形状特徵の一つとし て、縦横比を用いる。縦横比であれば、奥行きによる影響 を受けることはなく、また人間の形状特徵の中でも值の範 囲をある程度絞ることができるので、有効性が高いと考え たからである。

このための前処理として、得られた移動体領域データを ラベリングされた領域ごとに直方体の形状に変換する。こ こでは、各領域を座標軸に平行な最小外接矩形に変換する。 次に、変換後の形状を用いて、それぞれの直方体領域デー タごとの縦横比を計算する。

サンプル画像に縦横比の計算を行った画像を図 5 に示す。

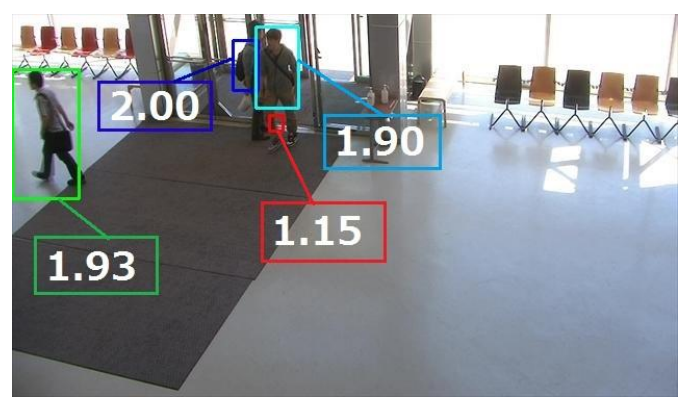

Fig.5 Aspect ratio image
こうして得られた各領域の縦横比に基づいて、領域を限 定する。本研究では、

$1.1<$ 縦横比 $<4.0$

を満たす領域を人領域の可能性があるものと判断する。図 5 の場合、赤枠で表示されている領域の縦横比は 1.15 なの で、除去されないことになる。このような不要領域を除去 するために、領域の大きさが一定值以下のものを除去する よう、面積による領域限定処理を行う。

\section{5. マッピング}

得られた人領域データを活用し、人の移動に関する知見 を得るための方法として採用したマッピングについて述べ る。マッピングは、得られた領域データを追跡し、用意し たマップ上にその座標データを順次表示していくものであ る。マップを等間隔の格子状に分割しておけば、各格子の 通過回数を知ることができるので、その分布を様々な目的 に利用することが可能になる。映像データから得られた人 領域を半径 1.5pixel の円に形状変換してマップ上に表示す るだけでは、人の動きに関する知見を得ることは容易では ない。よって、視認性を良くするためにこれらのデータを 加工し、人の動きの情報を捉えやすくする工夫が必要であ る。そこで、以下の条件に従って色分けし、各格子の通過 人数の分布を示すような分布図を作製した。分布図の一例 を図 6 に示す(この際、見やすくするため周囲を黒枠で囲っ ている)。

$<$ 条件 $>$

領域数が 1 未満 : 白色

領域数が 1 から 3 末満: 青色

領域数が 3 から 5 未満: 緑色

領域数が 5 以上: 赤色

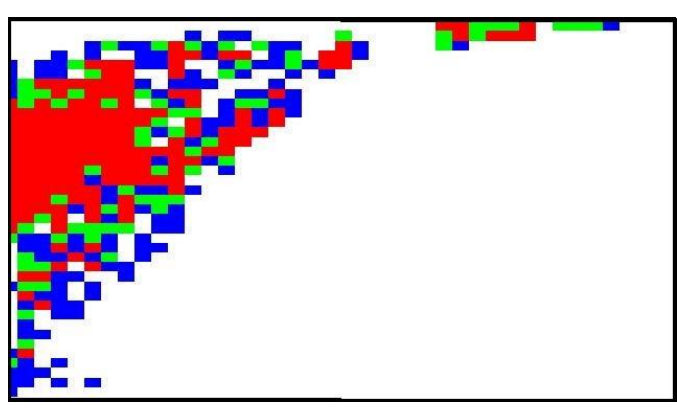

Fig.6 Distribution map

\section{6. 結言}

様々な用途での使用が考えられる人検出処理に関する手 法の検討を行った。本研究で提案する画像処理方法は、才 プティカルフローによる移動体検出を行った後、領域分割 処理を行い、さらに人間の形状特徽を考慮して人領域の特 定を行うものである。また、人領域の検出結果のデータ活 用方法についても検討した。

結果として、オプティカルフローから得られたデータを 元にして、そこから分水嶺アルゴリズムと、より効果的な 特徵量による人領域の特定方法によって、高い精度での人 領域の検出ができた。また、格子状のマップを利用したマ ッピングにより、応用面である程度の知見を得られること がわかった。しかし、人検出においては、最適閾值の決定 自動化という課題が残り、マッピングの方法もさらに工夫 する必要がある。 